\title{
Macromolecules with Carbohydrate Residues and Their Application in Glycobiology, Biotechnology and Material Science
}

\author{
Anna K. Bolsheborodova, ${ }^{\circledR}$ and Yuri L. Sebyakin \\ M.V. Lomonosov Moscow State University of Fine Chemical Technology, 119571 Moscow, Russia \\ ${ }^{\circledR}$ Corresponding authorE-mail: c-221@yandex.ru
}

\begin{abstract}
The paper provides a short review about synthesis and research of macromolecules with carbohydrate residues. In recent years, research in the field of carbohydrate chemistry was focused on design and production of artificial glycoconjugates analogues containing the same structural and functional elements, i.e. neoglycoconjugates. Synthetic carbohydrate structures may possess similar natural properties, simulate various biological processes or stages used in biochemical research in obtaining antibodies to carbohydrate determinants, serve as selective delivery vectors into cells and be used as affinity chromatography sorbents. The paper also discusses the principles of glyconanoparticle (GNP) formation and their possible exploration in glycobiology and material science. Common ways of neoglycoconjugates research to study or to assess interactions with various classes of compounds, as well as for the creation of artificial antibacterial vaccines, biomimetics and contrast agents in magnetic resonance imaging (MRI) were reflected.
\end{abstract}

Keywords: Neoglycoconjugates, glyconanoparticles, glycobiology, glycovirus, biomimetics, glycopolymers.

\section{Углеводсодержащие макромолекулы и их применение в гликобиологии, биотехнологии и материаловедении}

\author{
А. К. Большебородова, ${ }^{\circledR}$ Ю. $\curlywedge$. Себякин \\ Московский государственный университет тонких химических технологий имени М.В. Ломоносова, 119571 Москва, \\ Россия \\ ${ }^{\circledR}$ E-mail: c-221@yandex.ru
}

\begin{abstract}
Статья является кратким обзором работ, посвященных синтезу и исследованию углеводсодержсащих макромолекул. В последние годы исследования в области химии углеводов все больше нацелень на дизайн и получение искусственных аналогов гликоконъюгатов, содержащих те же структурные и функциональные элементы - неогликоконъюгаты. Синтетические углеводные конструкции могут обладать аналогичными природным соединениям свойствами, моделировать различные биологические прочессы или их стадии, использоваться в биохимических исследованиях, при получении антител к углеводным детерминантам заданной структуры, служить векторами селективной доставки в клетки биологически активных веществ, применяться в аффинной хроматографии в качестве сорбентов. В статье также обсуждаются принципь создания гликонаночастиц и возможности их использования в гликобиологии и материаловедении; отражены распространенные пути исследования неогликоконъюгатов для изучения или оценки взаимодействий с различными классами соединений, создании на их основе искусственных антибактериальных вакцин, биомиметиков и контрастирующих агентов для магнитно-резонансной томографии (МРТ).
\end{abstract}

Ключевые слова: Неогликоконъюгаты, гликонаночастицы, гликобиология, гликовирус, биомиметики, гликополимеры. 
Along with proteins and lipids, carbohydrates are among the most important chemical constituents of living organisms. Carbohydrates have numerous functions in human and animal organisms: as an energy source (the main type of cell fuel), structural (a mandatory component in the majority of intracellular structures), and protective function (participation of carbohydrate components of immunoglobulins in immunity maintenance). In complexes with nucleic acids or peptides, carbohydrates form glycoconjugates that are compounds involved in main biochemical processes. Synthetic analogues of such natural carbohydrate structures were called neoglycoconjugates. Neoglycoconjugates are unique tools for the study of carbohydrate-binding proteins of the cell surface that can be used to modify biological processes. ${ }^{[1]}$

The main problem in the synthesis of neoglycoconjugates is creating a reactive functional moiety in the carbohydrate component, which allows bioactive molecules to be bound to it subsequently. However, the procedure of neoglycolconjugate assembly has a number of

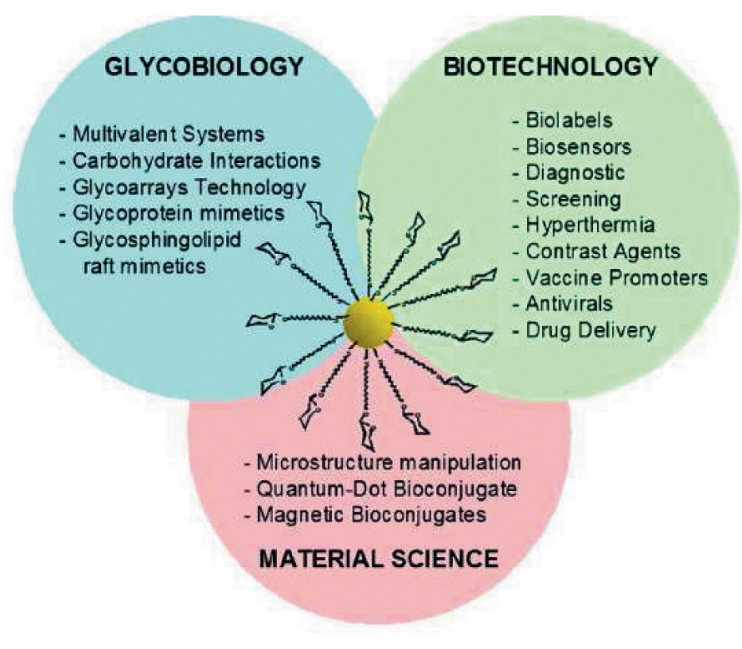

Figure 1. Possible applications of neoglycoconjugates. considerable limitations. The reactions and reagents used in the procedure should be compatible both with the reactive groups of the aglycone and with carbohydrate moieties, should not cause modifications of the terminal glycoside residue or affect the surface charge of proteins, and should provide high yields. ${ }^{[2]}$

The chemistry of neoglycoconjugates covers a wide area of synthetic carbohydrate derivatives with specific structures and properties. It is reported rather often in recent publications on the synthesis of similar structures that these compounds are used for the study and evaluation (both qualitative and quantitative) of specific reactions with various classes of compounds, as well as for the creation of artificial antibacterial vaccines, biomimetics, biosensors, and reagents for diagnostics on this basis, thus opening new approaches in chemical glycobiology and biomedicine (Figure 1).

\section{Neoglycoconjugates in Glycobiology}

The problem of low affinity in various types of carbohydrate interactions, despite their rather high selectivity, is overcome by grouping of ligands and receptors on the cell surface into complicated multivalent complexes. Such associative influence makes them multifunctional in the bond formation. To understand the mechanisms of these processes, complex model systems were developed based on spherical or linear carbohydrate associates, such as glycodendrimers (1), glycopolymers (2), glycopeptides, and glycoproteins, as well as self-organizing systems, such as micelles and liposomes (Figure 2). ${ }^{[3]}$

In search for new multivalent complexes with distinct chemical composition, some research teams used metalbased glyconanoparticles (GNP) (Figure 3). ${ }^{[4]}$

The advantages they afford in comparison with the other obtained colloids before include: facility of preparation and purification, exceptionally small core size, narrow range of particle size variation, controlled number of ligands, water solubility, high stability, unusual physical properties, and absence of cytotoxicity. Furthermore, it is possible to modify GNP by various molecules, such as fluorescent labels, biotin,

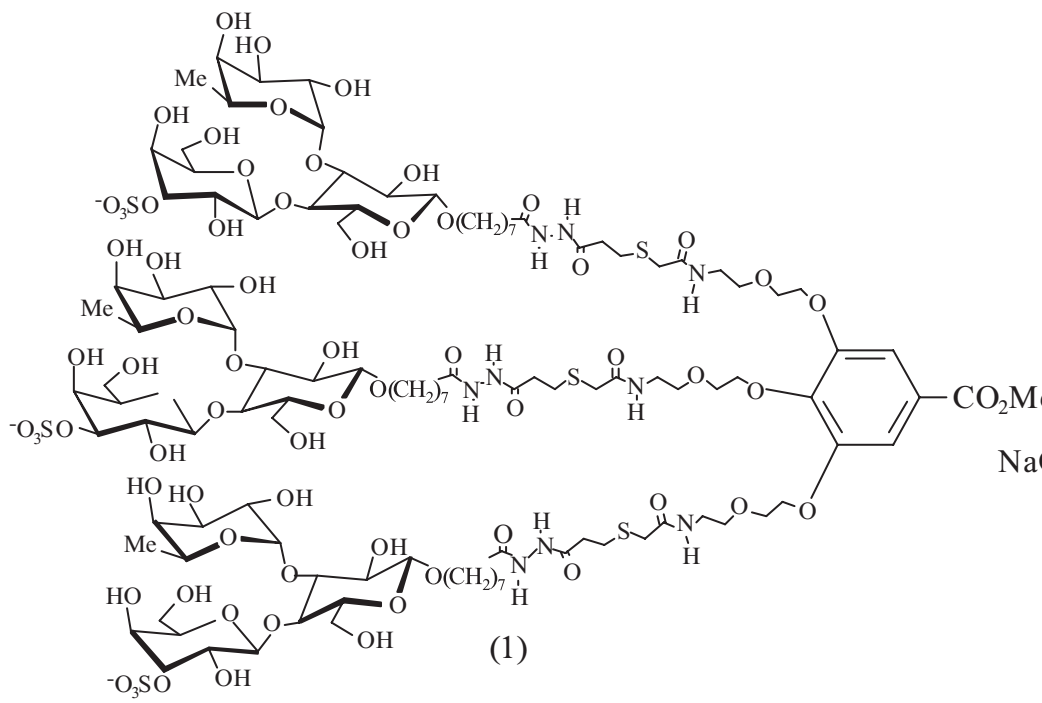

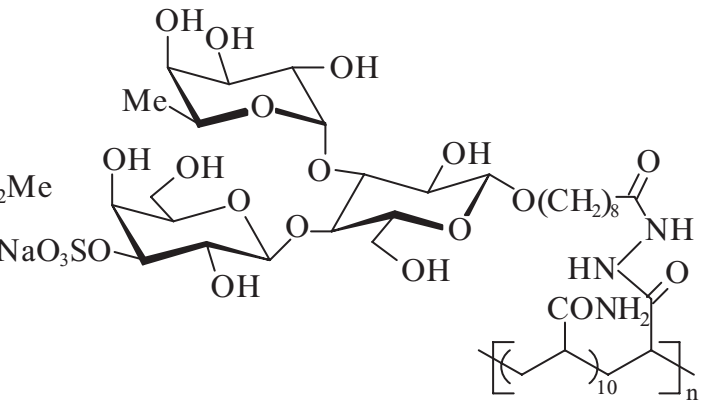

Figure 2. Glycodendrimers (1) and glycopolymers (2) structures. 


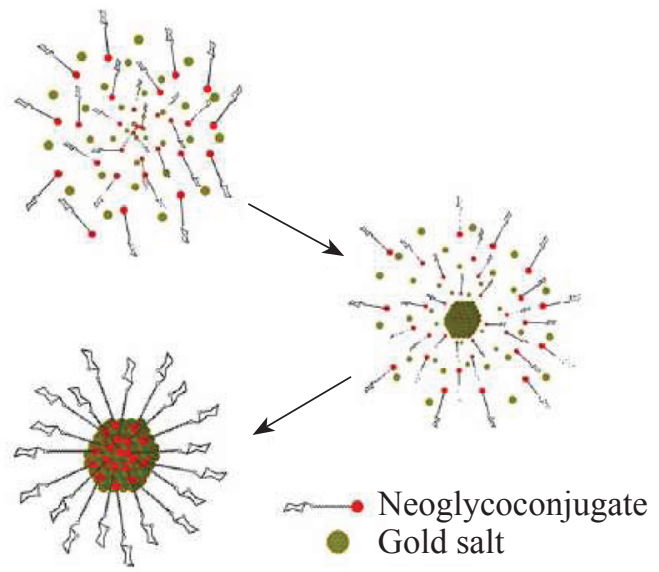

Figure 3. The mechanism of GNP formation. Adapted from ${ }^{[4]}$.

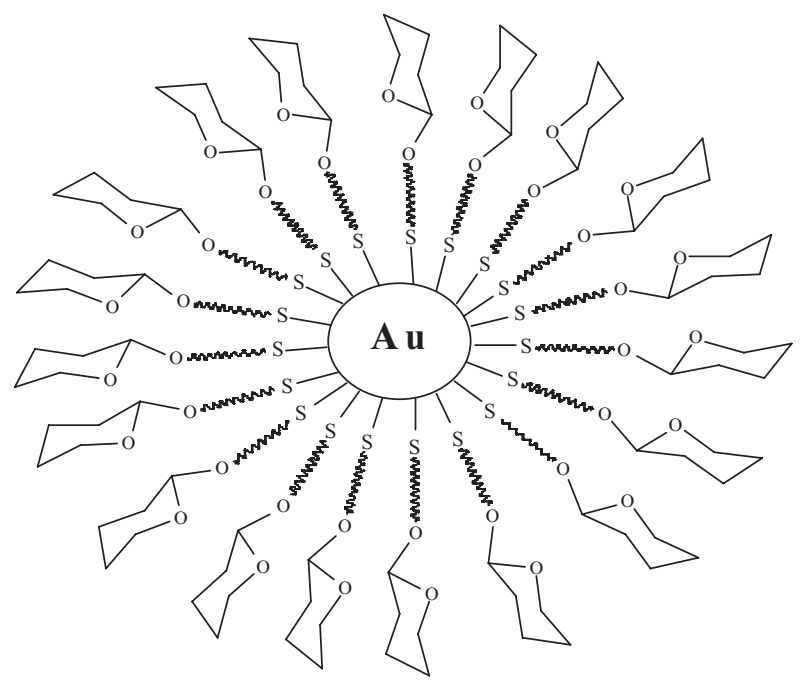

Figure 4. Structure of gold glyconanoparticles modified by Le $\mathrm{e}^{\mathrm{x}}$, Le $^{y}, D$-glucose, $D$-maltose and lactose. peptides, DNA, and RNA, in order to obtain multifunctional transport systems.

In order to study the selectivity of carbohydrate-protein and carbohydrate-carbohydrate interactions, gold-based nanoparticles functionalized with lactose or a trisaccaride $\left(\mathrm{Le}^{\mathrm{x}}-\mathrm{Au}\right)$ (Figure 4) were constructed. ${ }^{[5]}$

Synthetic carbohydrate mimetics in which carbohydrates have a certain spatial configuration are important constructs in glycobiology. The compounds obtained contain a rather rigid 1,4-substituted part of triazole that is well suited for structural mimetics of the carbohydrate ring. ${ }^{[6]}$

As carbohydrate clusters are formed, the azide primarily adds to the carbohydrate. It was found that direct addition of a triazol to a carbohydrate can affect sugar recognition by receptors, hence short or long alkyl spacers are incorporated in the cluster and glycoconjugate core. ${ }^{[7]}$

A synthesis of clusters of C-bound pyranose (3) (Figure 5) using various types of aromatic or calixarene molecules in order to ensure a straight or globular spatial distribution of the carbohydrate was reported in Ref. ${ }^{[8]}$

Mimetics of this kind are particularly attractive in the case of natural or synthetic glycopeptides that are expensive or hard to obtain in large quantities.

\section{Neoglycoconjugates in Biotechnology}

\section{Lectins}

Undoubtedly, cell receptors are convenient targets for selective delivery of bioactive compounds to certain organs or tissues. Such receptors include carbohydrate-recognizing proteins, lectins, that are present on the surface of animal, plant, and microorganism cells and play an important role in the recognition of other cells, viruses, and bacteria. Dozens of membrane lectins with various kinds of carbohydrate specificity have been characterized; some of them readily deliver their own ligands to intracellular compartments, including endosomes, lysosomes, and Golgi's apparatus.

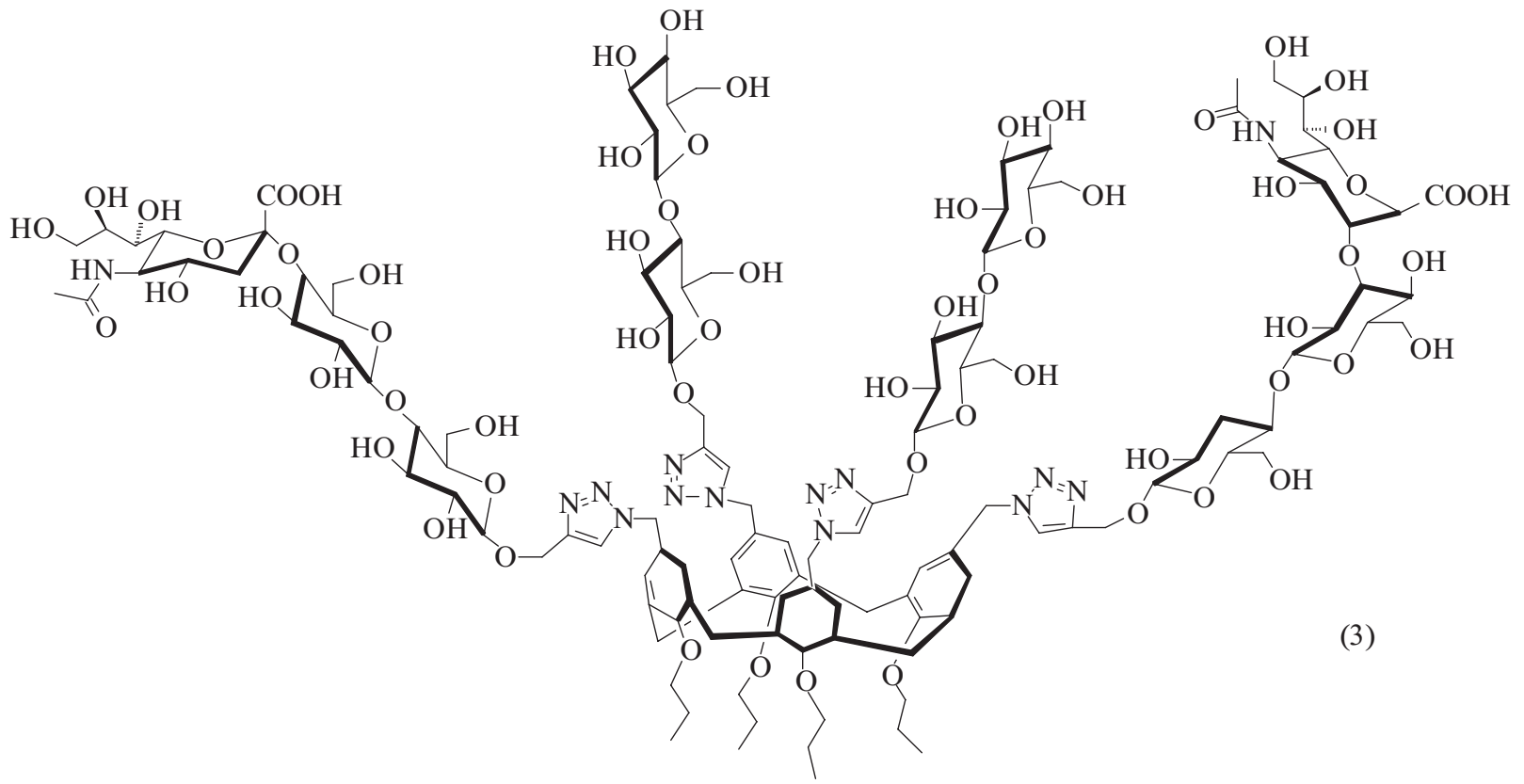

Figure 5. Structure of clustered C-bound pyranose. 
Of the entire diversity of lectin receptors, those located on cancer cells and on the surface of vital human organs are of the greatest interest. It was found that the majority of them have a certain structure responsible for recognition, therefore creation of high affinity compounds allows them to be used as vectors for directed drug transport. ${ }^{[11]}$

\section{Neoglycoconjugates as Ligands for Directed Delivery of Bioactive Compounds}

Liposomes are the most thoroughly studied nanosystems for the transport of drugs and genetic material. Owing to the similarity with cell membranes, they have rather low cytotoxicity, are biodegradable and can be absorbed by cells under certain conditions, which results in intracellular delivery of their content. Furthermore, a compound enclosed in a liposome is protected from exposure to enzymes, which favors the efficiency of agents that are liable to biodestruction in biological fluids. ${ }^{[12]}$

The former problem can be solved by modification of particle surfaces by polymers with flexible hydrophilic chain, such as polyethylene glycol $(P E G)$. Target properties are imparted to liposomes by functionalization of their surfaces with various macromolecules, including natural oligosaccharides or neoglycoconjugates specific to a certain type of cell receptors (Figure 6).

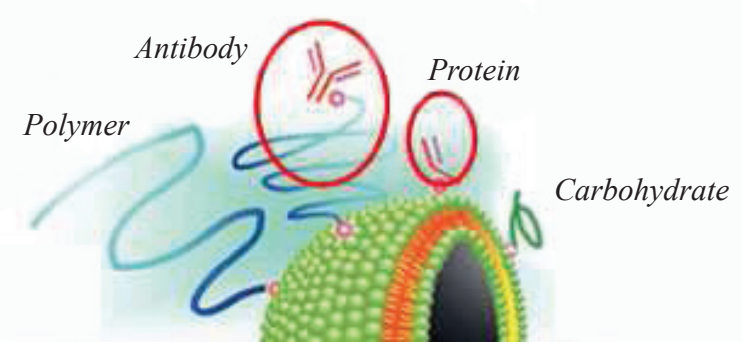

Figure 6. Schematic representation of liposome modified by a variety of macromolecules.

An example of specific transport systems is given by liposomes modified by various carbohydrate residues that serve as a molecular recognition signal for target cells. In order to increase the binding constant of sugar residues with specific proteins on cell surfaces, multivalent or cluster derivatives are used more and more often.

Glycoclusters (or "cluster" glycosides) are similar in structure to natural oligoantennary glycoconjugates.

Table 1. Galectins and their role in organism..$^{[9,10]}$

\begin{tabular}{|c|c|c|c|c|c|}
\hline$\frac{\Xi}{\stackrel{\Xi}{0}}$ & Prevalent distribution & $\begin{array}{l}\text { Regulation in } \\
\text { systems }\end{array}$ & Up-regulation & Down-regulation & 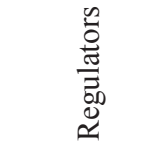 \\
\hline 1 & $\begin{array}{c}\text { Most tissues: skeletal, heart, } \\
\text { placenta, lymphatic tissues, } \\
\text { etc. }\end{array}$ & $\begin{array}{l}\text { Cell's grow, } \\
\text { apoptose, cell's } \\
\text { cycle }\end{array}$ & $\begin{array}{l}\text { Most transformed cell } \\
\text { lines and tumors. Chronic } \\
\text { pancreatitis. Parasites } \\
\text { infection }\end{array}$ & $\begin{array}{l}\text { Tumors: head and } \\
\text { neck }\end{array}$ & $\begin{array}{l}\text { Azacytidin, } \\
\text { butyrate }\end{array}$ \\
\hline 2 & Gastro- intestinal tract & $\begin{array}{l}\text { Cell's grow, cell's } \\
\text { cycle }\end{array}$ & & & \\
\hline 3 & Macrophages, epithelia & $\begin{array}{l}\text { Cell's grow, cell's } \\
\text { cycle, adhesion }\end{array}$ & $\begin{array}{l}\text { Tumors: thyroid, gastric, } \\
\text { CNS, large cell lymphomas. } \\
\text { Streptococcal pneumonia }\end{array}$ & $\begin{array}{c}\text { Tumors: breast, } \\
\text { ovarian, prostate, head } \\
\text { and neck, basal cell. } \\
\text { HTLV-I infection }\end{array}$ & $\begin{array}{l}\text { Heat-shock, } \\
\text { trypsine }\end{array}$ \\
\hline 4 & Gastro-intestinal tract & & Tumors: liver, gastric & Tumors: colon & \\
\hline 5 & $\begin{array}{l}\text { Blastocyst at implantation, } \\
\text { reticulocytes }\end{array}$ & & & & \\
\hline 6 & Gastro-intestinal tract & & & & \\
\hline 7 & Epithelia & $\begin{array}{l}\text { Gene expression, } \\
\text { that control } \\
\text { apoptose }\end{array}$ & Tumors: breast & Tumors: bladder, skin & \\
\hline 8 & $\begin{array}{l}\text { Liver, kidney, cardiac muscle, } \\
\text { lung, brain, colon }\end{array}$ & $\begin{array}{l}\text { Cell's grow, } \\
\text { adhesion }\end{array}$ & $\begin{array}{c}\text { Tumors: pancreas, liver, skin, } \\
\text { larynx }\end{array}$ & Tumors: Colon & \\
\hline 9 & $\begin{array}{l}\text { Eosinophils, monocytes, } \\
\text { macrophages, gastro-intestinal } \\
\text { tract, melanocytic nevi }\end{array}$ & Apoptose & $\begin{array}{l}\text { Hodgkin's lymphomas. } \\
\text { Allergic and parasitic } \\
\text { response. }\end{array}$ & Tumors: melanoma & \\
\hline 9 & Kidney, gastro-intestinal tract & & Hodgkin’s lymphomas. & Tumors: melanoma & \\
\hline 10 & Eosinophils, basophils & & & & \\
\hline 11 & Lens & Cell's grow & & & \\
\hline 12 & Adipocytes & & Cell cycle: G1 phase & & \\
\hline 13 & Placenta & & & & \\
\hline 14 & Eosinophils & & Allergic response & & \\
\hline
\end{tabular}




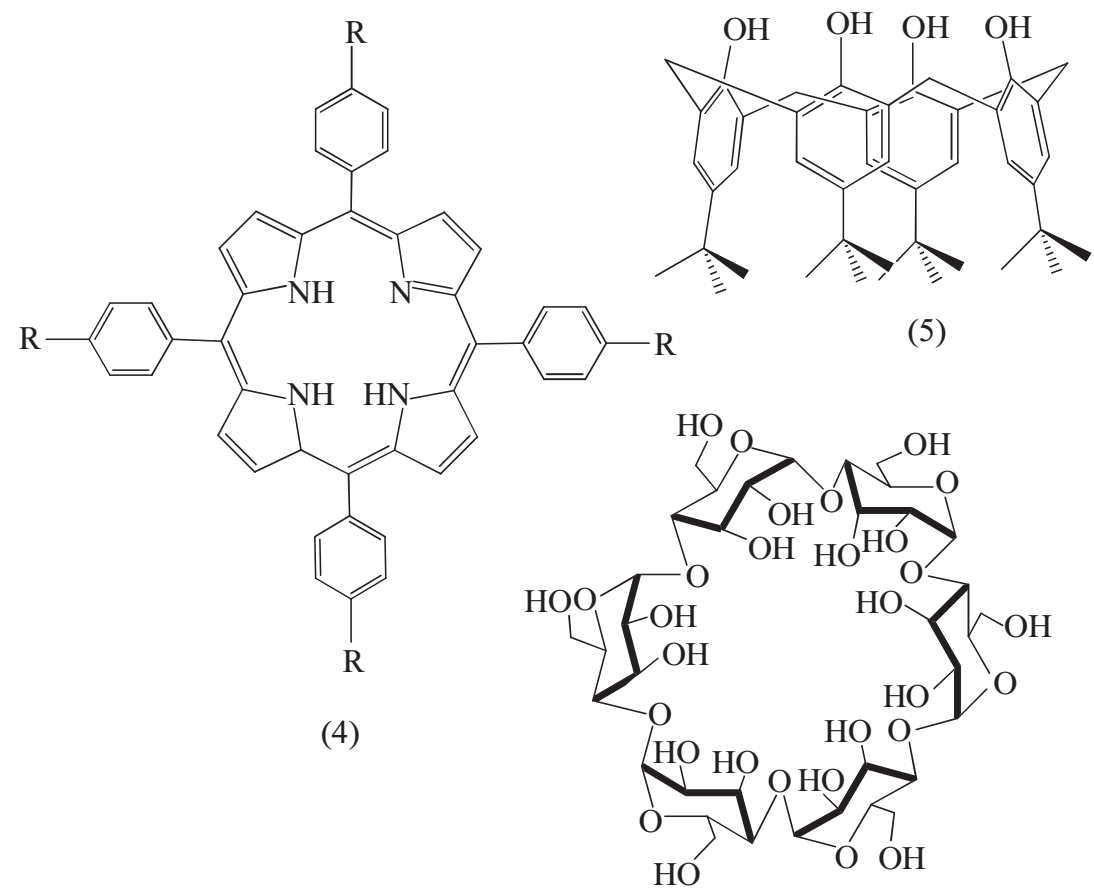

(6)

Figure 7. Examples of scaffolds for glycoclusters.

Numerous syntheses of similar structures based on various scaffolds have been reported.

For example, branched aliphatic and aromatic scaffolds, such as porphyrins (4), calyxarenes (5), derivatives of cyclic peptides and carbohydrates (6), and cyclodextrins ${ }^{[13-15]}$ were efficiently used (Figure 7).

The detection of pathogenic bacteria is very important in the qualitative monitoring of foodstuffs and water, in ecological monitoring, and in clinical diagnostics. Carbohydrate-based detection is a promising alternative to the standard methods used for the detection and protection from bacterial infections. ${ }^{[16]}$

\section{Carbohydrate Microchips}

The use of microchips is an inexpensive and highly specific method for fast high-quality study of a large number of biomolecular interactions. The creation of carbohydratecontaining microscaffolds changed considerably our ability to study the carbohydrate-mediated bonding on molecular level. In fact, polyanionic glycopolymers (Figure 8) applied onto gold electrodes find broad use for the detection of bacterial toxins and adhesion proteins. ${ }^{[17]}$

Furthermore, it was obtained a series of artificial glycopolymers $(\mathbf{7}, \mathbf{8})$, that can sorb pathogenic E.coli $O-157$ bacteria and the shiga toxin they produce (Figure 9). ${ }^{[18]}$

\section{Carbohydrate-Containing Carbon Nanotubes}

Carbon nanotubes $(C N T S)$ attract great interest of scientists owing to their unique structural, mechanical, and electronic properties. ${ }^{[19]}$ They are particularly interesting as biosensors due to their exceptional chemical and biochemical stability and ability to manifest strong fluorescence in the short-wave IR region (800-1600 nm). ${ }^{[20]}$

$\mathrm{Gu}$ et al. used carbon nanotubes coated with a galactosyl monolayer (Gal-SWNTs) (Figure 10) as multivalent ligands for specific binding with E. coli. It was shown by scanning electron microscopy that, firstly, selective recognition of $E$. coli Gal-SWNTs took place,

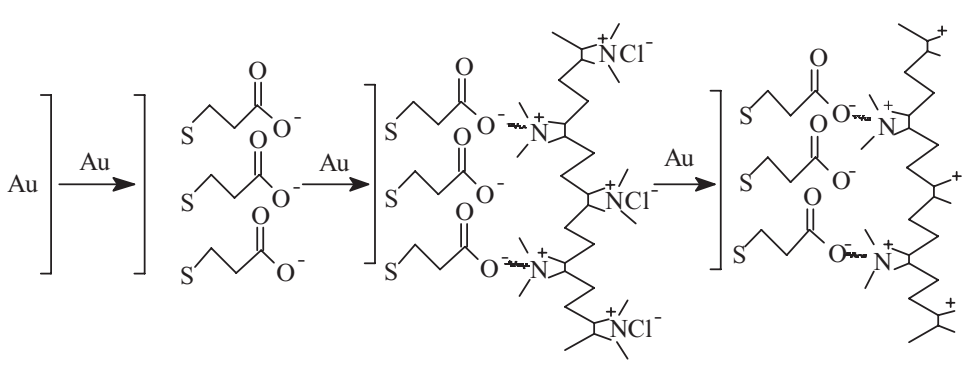

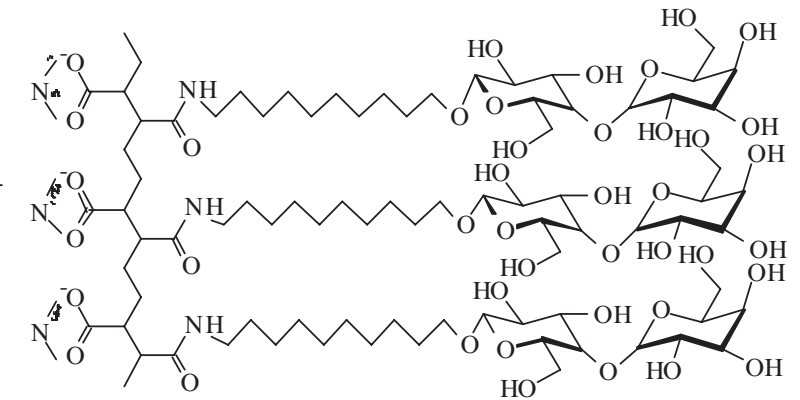

Figure 8. Polyanionic glycopolymers on gold nanoparticles. 


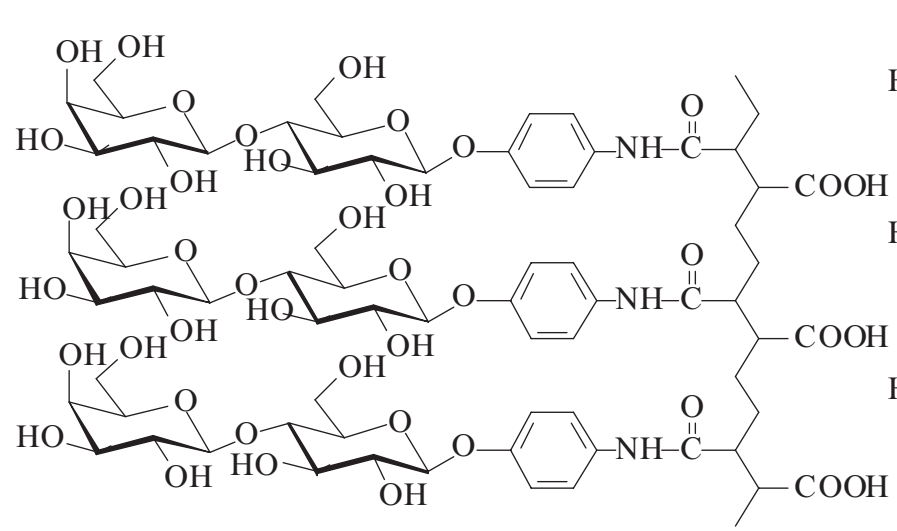

(7)

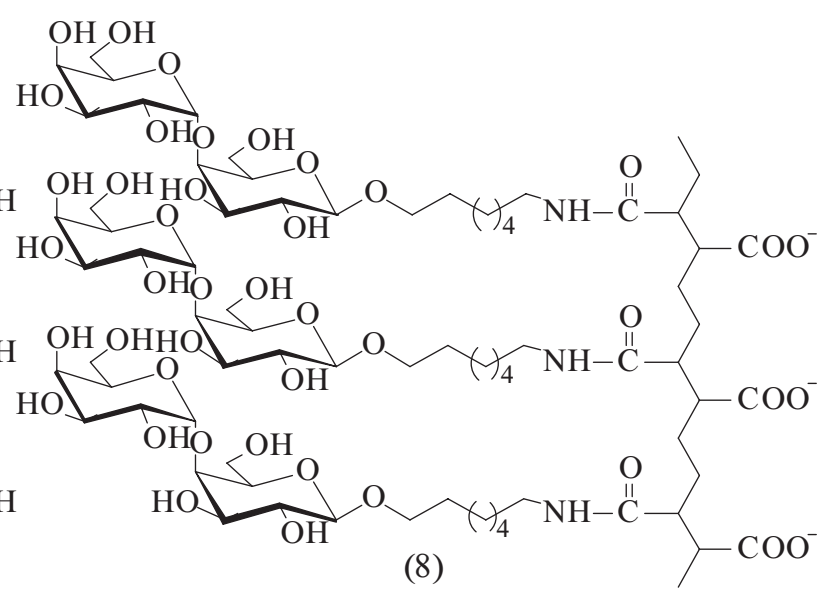

Figure 9. Glycopolymers that can sorb toxins.

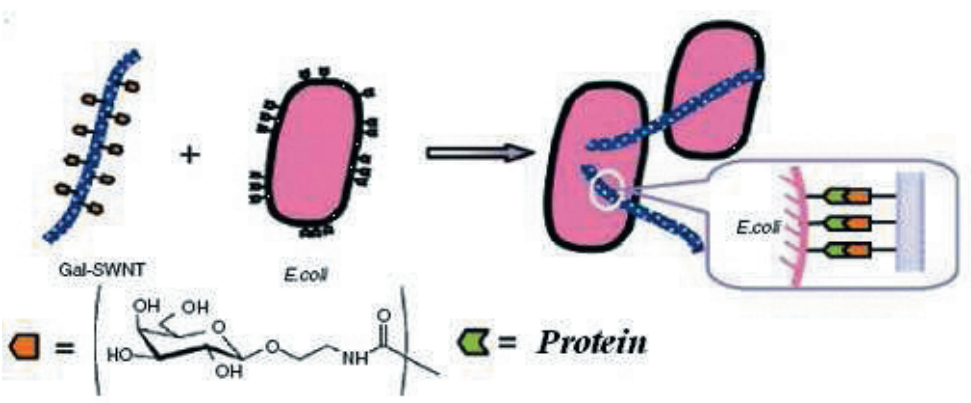

Figure 10. E. coli modification. Adapted from ${ }^{[21]}$.

and secondly, no interactions occurred under the same experimental conditions if Gal-SWNTs was replaced by SWNTs modified with $\alpha-D$-mannose (Man-SWNTs) or bovine serum albumin. ${ }^{[21]}$

It was shown that Gal-SWNTs and Man-SWNTs can be used as sensitive systems for the detection of Bacillus anthracis spores. ${ }^{[22]}$

\section{Fluorescent Glycopolymers}

Conjugates of fluorescent glycopolymers, such as glycopoly- $p$-phenylene-ethynylenes, glycopolythiophenes, glycopoly- $p$-phenylenes, and carbohydrate-modified polydiacetylenes, were obtained for fast detection of $E$. Coli owing to multivalent interactions between the carbohydrate residues and bacteria lectins. ${ }^{[23-25]}$ As these compounds incorporate a fluorescent marker and a glycoside component, they display an interesting combination of properties: fluorescence and high sensitivity to the external signal.

\section{Antiviral Agents}

Penades et $a l .{ }^{[26]}$ studied whether it is possible to use gold-based glyconanoparticles to control the binding of the human immunodeficiency virus (HIV) with dendrite cells and subsequent propagation of the infection.

The main mechanism of HIV penetration is based on the interaction of gp120 glycoprotein located on its surface with the DC-SIGN receptor expressed on dendrite cells. DC-
SIGN is a transmembrane protein that selectively recognizes endogenous mannose residues in oligosaccharide structures of the gp120 glycoprotein.

The assumption was made that glyconanoparticles modified by mannoside components would be recognized by DC-SIGN receptors, interact with them, and thus inhibit viral adhesion to dendrite cells.

\section{Transport of Drugs and Genetic Material}

The efficiency of drugs is largely determined by their ability to migrate in the organism and reach the sick tissue in therapeutically significant amounts. Therefore, drug delivery systems created in order to improve the pharmacological properties of drugs are among the most important directions in therapeutic studies.

Recently, the method for neoglycopeptide synthesis with the use of olefins became widely popular. A specific feature of this method is that the final glycosylamino acids can be easily incorporated in peptide-like glycoclusters or glycopeptides. The use of this method for synthesizing glycopeptide (11) and oligoglycine (13) scaffolds, ${ }^{[27]}$ $C$-glycosyl oligopeptide (16), ${ }^{[28]}$ as well as a synthesis of compounds based on $C$-fucosylpeptide $(\mathbf{1 7})^{[29]}$ have been reported. As a result, comparatively powerful $P$-selectinantagonists were obtained (Figure 11).

Aside from neoglycoproteins, polymers were suggested as drug delivery agents. The importance of polymer systems increased due to the arrival of biodegradable polymer 
<smiles>C=CCC1OC2(Br)C(Br)C(Br)C1C(OBr)C2COCc1ccccc1</smiles>

(9)

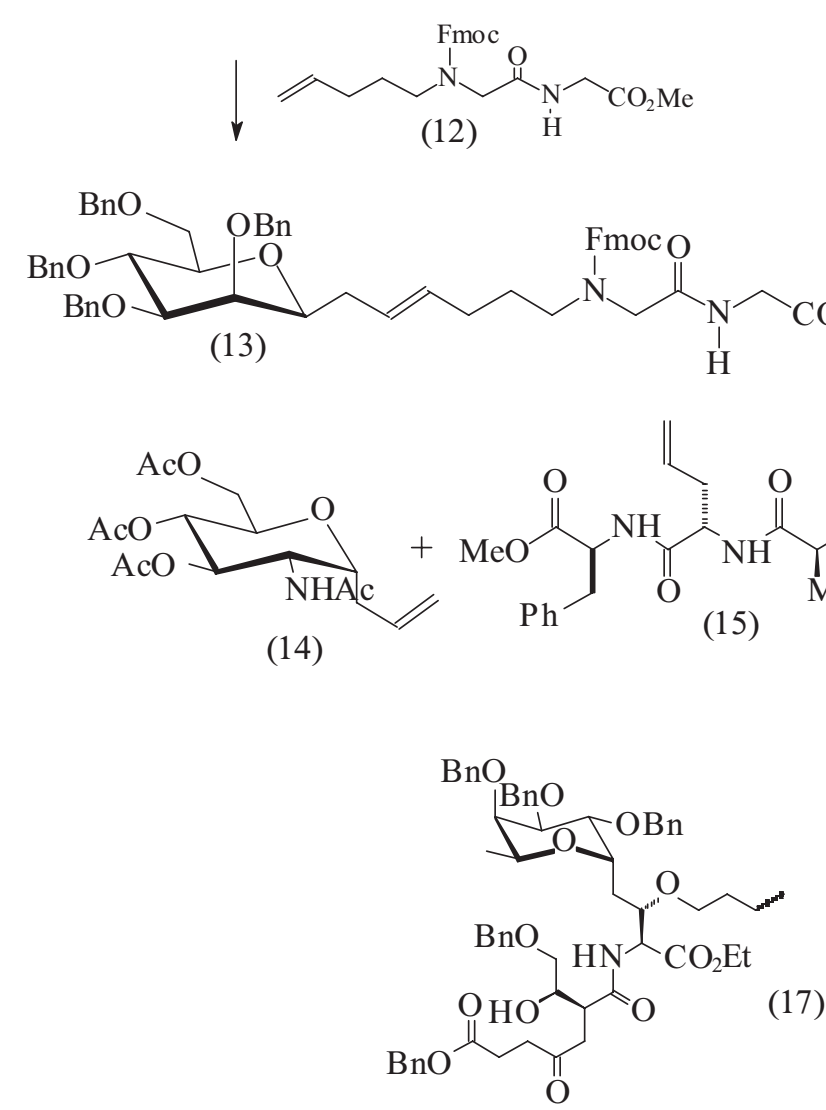<smiles>CC(=O)NC(C/C=C/CC1OC(O)(COCc2ccccc2)C(OCc2ccccc2)C(OBr)C1OCc1ccccc1)C(=O)OCc1ccccc1</smiles>

Figure 11. $P$-selectin-antagonists synthesis.

implants. They are used in this form as a subcutaneous depot that slowly releases a drug and provides a local therapeutic effect.

Such systems also include hydrogels, i.e., cross-linker three-dimensional networks of hydrophilic polymers that swell in water to a size much larger than the original one but do not dissolve. Synthesis of carbohydrate-based hydrogels attracts the attention of researchers due to the biocompatibility and hydrophilic nature of sugars. Hydrogels containing a certain carbohydrate can improve the cell adhesion and growth. Lactose based hydrogels have been synthesized, including thermosensitive ones, and the options of their use have been studied. ${ }^{[30]}$

\section{Use of Neoglycoconjugates in Gene Therapy}

Transfection into animal cells using cationic vectors is a standard technique in cytobiology. Starting from the discovery of lipofectin in 1987, much interest in non-viral gene delivery systems has been shown. Cationic gene transporters are classified into two main types: liposomeforming lipids and covalent polymer/dendrimers. They are bound with anionic DNA by electrostatic attraction forces. A cell captures the resulting complexes, also known as lipoplexes and polyplexes, respectively, by endocytosis to launch a series of complex intracellular processes that

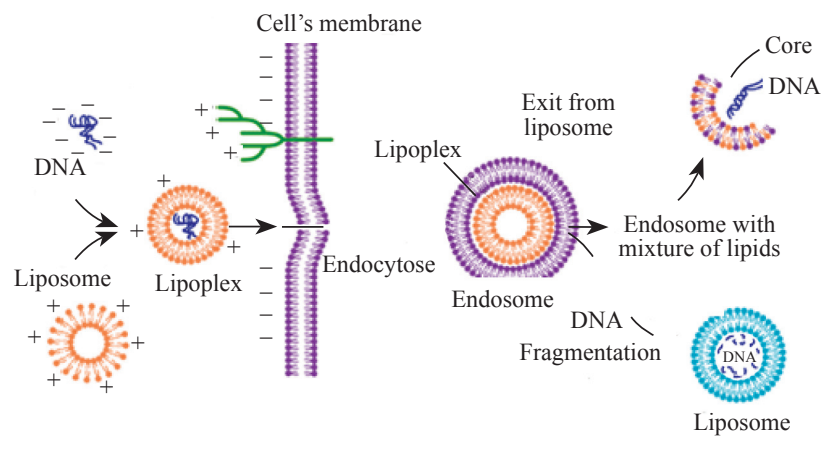

Figure 12. Lipoplex-mediated transfection and endocytosis.

eventually result in the expression of the gene being coded (Figure 12).

We have recently developed a new type of structures, namely, carbohydrate-containing macrocycles currently called as glycoviruses. Octaamine $(\mathbf{1 8}, \mathbf{1 9})$ has eight long alkyl residues and eight amino groups, all or some of which are glycosylated (Figure 13). ${ }^{[31]}$

Lactose modification of macrocycle (19) and its DNAconjugates "mask" the positive charge, thus decreasing considerably the toxicity of complexes, on the one hand, and improving the efficiency of recognition by asialoglycoprotein receptors (Figure 14). ${ }^{[32]}$ 


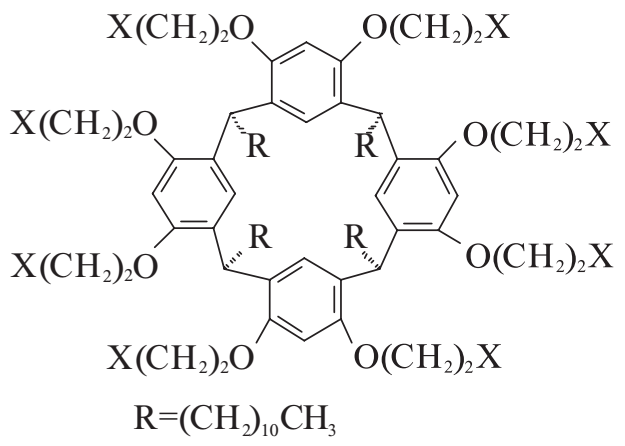

(18) $\mathrm{X}=\mathrm{NH}_{2}$

(19) $\operatorname{Lac}(n):(8-n) X=\mathrm{NH}_{3}^{+} \mathrm{Cl}^{-}$

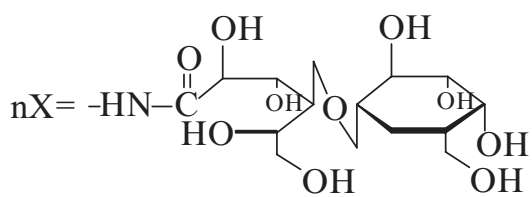

Figure 13. Glycovirus structure.

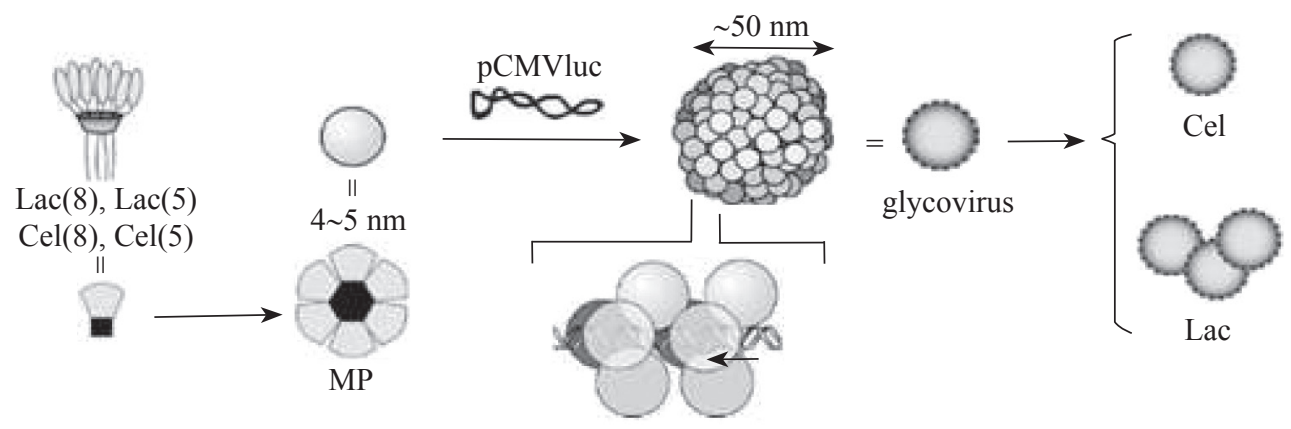

Figure 14. Glycovirus formation. Adapted from ${ }^{[32]}$.

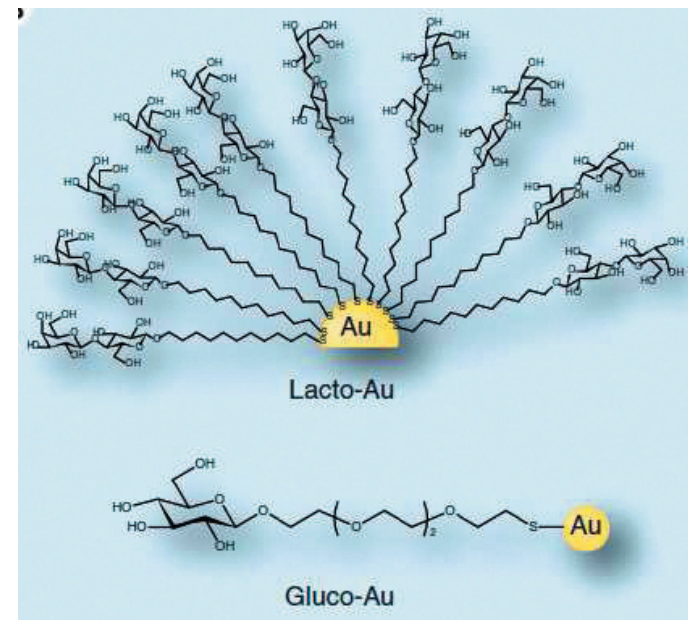

Figure 15. Gold nanoparticles modified with carbohydrate residues. Adapted from ${ }^{[33]}$.

\section{Glyconanoparticles in Materials Science}

Magnetic nanoparticles are used ever more frequently for hyperthermal treatment of mammal cells, targeted drug delivery, and cell membrane manipulation. The physicochemical features of these complexes are due to their high magnetization, small size (less than $20 \mathrm{~nm}$ ), and a special shell that decreases their toxicity and allows them to interact with various biomolecules. ${ }^{[33]}$

The importance of these systems is mainly due to their application as contrast agents in magnetic resonance imaging $(M R I)$, a method for the investigation of internal organs and tissues based on a physical phenomenon, nuclear magnetic resonance. This method allows one to study human organism based on the degree of hydrogen saturation of tissues.

Magnetic Au-Fe nanoparticles modified by $D$-glucose, $D$-maltose, and lactose residues were obtained for this purpose (Figure 15). The resulting complexes demonstrated magnetic properties with paramagnetic and ferromagnetic features. This anomalous behavior may be attributed to gold atoms, which predominate in metal clusters with $\mathrm{Au} /$ Fe atomic ratios from 50:1 to 5:1 and show permanent magnetism even at room temperature. ${ }^{[34]}$

\section{Conclusions}

Thus, due to the large structural diversity of neoglycoconjugates and extensive application area creation new systems with carbohydrates and study of their properties is quite interesting and relevant research problem. The main feature of these systems is a multivalent construction involved in carbohydrate-mediated interactions offering new possibilities in glycobiology and giving interesting physical, biological and chemical properties.

Acknowledgements. This study was financially supported by the Russian Foundation for Basic Research (Grant №. 1104-01618).

\section{References}

1. Fuente J., Penadés S. Biochim. Biophys. Acta, Gen. Subj. 2006, 1760, 636-651.

2. Ashwell G., Harford J. Annu. Rev. Biochem. 1982, 51, 531-554. 
3. Roy R., Tropper F., Morrison T., Boratynski J. J. Chem. Soc., Chem. Commun. 1991, 23, 536-537.

4. De la Fuente J.M., Barrientos A.G., Rojas T.C., Rojo J., Cañada J., Fernández A., Penadés S. Angew. Chem., Int. Ed. 2001, 40, 2257-2261.

5. Paz J.L., Ojeda R., Barrientos A.G., Penadés S., Martín-Lomas M. Tetrahedron: Asymmetry 2005, 16, 149-158.

6. Liebert T., Heinze T. Macromol. Rapid Commun. 2006, 27, 208.

7. Hein C., Liu X-M., Wang D. Pharm. Res. 2008, 25, 22162230.

8. Dondoni A., Marra A. J. Org. Chem. 2006, 71, 7546.

9. Anderson K., Evers D., Rice K.G. Glycoscience 2008, part 12, 2445-2482.

10. Leffler H., Carlsson S., Hedlund M., Qian Y., Poirier F. Glycoconjugate J. 2002, 19, 433-440.

11. Chiariotti L., Salvatore P., Frunzio R, Bruni C. Glycoconjugate J. 2002, 19, 441-449.

12. Anderson K., Evers D., Rice K.G., Structure and Function of Mammalian Carbohydrate-Lectin Interactions. In: Glycoscience (Fraser-Reid B., Tatsuta K., Thiem J., Eds.). Heidelberg: Springer-Verlag Berlin, 2008. p. 2445-2483.

13. Niidome T., Hung L. Gene Ther. 2002, 9, 1647-1652.

14. Roy R. Trends Glycosci. Glycotechnol. 2003, 15, 291-310.

15. Chabre Y.M., Roy R. Curr. Top. Med. Chem. 2008, 8, 12371285.

16. Perez-Balderas F., Morales-Sanfrutos J., Hernández-Mateo F., Isac-Garciá J., Santoyo-González F. Eur. J. Org. Chem. 2009, 9, 2441-2453.

17. Lindhorst T.K., Kotter S., Krallmann-Wenzel U., Ehlers S. J. Chem. Soc., Perkin Trans. 2001, 1, 823-831.

18. Uzawa H., Ito H., Izumi M., Tokuhisa H., Taguchi K., Minoura N. Tetrahedron 2005, 61, 5895-5905.

19. Chen J.R., Miao Y.Q., He N.Y., Wu X.H., Li S.J. Biotechnology Advances 2004, 22, 505-518.
20. Jeng E.S., Moll A.E., Roy A.C., Gastala J.B., Strano M.S. Nano Lett. 2006, 6, 371-375.

21. Gu L.R., Elkin T., Jiang X.P., Li H.P., Lin Y., Qu L.W., Tzeng TR.J., Joseph R., Sun Y.P. Chem. Commun. 2005, 874-876.

22. Wang H.F., Gu L.R., Lin Y., Lu F.S., Meziani M.J., Luo P.G.J., Wang W., Cao L., Sun Y.P. J. Am. Chem. Soc. 2006, 128, 13364-13365.

23. Disney M.D., Zheng J., Swager T.M., Seeberger P.H. J. Am. Chem. Soc. 2004, 126, 13343-13346.

24. Baek M.G., Stevens R.C., Charych D.H. Bioconjugate Chem. 2000, 11, 777-788.

25. Xue C.H., Jog S.P., Murthy P., Liu H.Y. Biomacromolecules 2006, 7, 2470-2474.

26. Penades S., de la Fuente J., Barrientos A., Clavel C., MartinezBvila O., Alcantara D. Multifunctional Glycinanoparticles: Applications in Biology and Biomedicine. In: Nanomaterials for Application in Medicine and Biology (Giersig M., Khomutov G.B., Eds.). Springer, 2008. p. 204.

27. Dominique R., Liu B., Das S., Roy R. Synthesis 2000, 35, 862868.

28. Fiume L., Busi C., Preti P., Spinosa G. Cancer Drug Delivery 1987, 4, 145-150.

29. Huwe C., Woltering T., Jiricek J., Weitz-Schmidt G., Wong C. Bioorg. Med. Chem. 1999, 7, 773-788.

30. Zhou W., Kurth M., Hsieh Y., Krochta J. J. Polym. Sci., Part A: Polym. Chem. 1999, 37, 1393-402.

31. Aoyama Y. Chem. Eur. J. 2004, 10, 588-593.

32. Shohei Horiuchi, Yasuhiro Aoyama J. Controlled Release 2006, 116, 107-114.

33. Tartaj P., Morales M., Veintemillas-Verdaguer S., GonzalezCarreño T., Serna C. J. Phys. D: Appl. Phys. 2003, 36, 182197.

34. Lopez-Cartes C., Rojas T., Litran R., Martinez-Martinez D., Fuente J., Penades S., Fernandez A. J. Phys. Chem. B 2005, 109, 8761-8766. 